\title{
Circulating haemopoietic and endothelial progenitor cells are decreased in COPD
}

\author{
P. Palange*, U. Testa\#, A. Huertas*, L. Calabrò\#, R. Antonucci*, E. Petrucci”, \\ E. Pelosi ${ }^{\#}$, L. Pasquini ${ }^{\#}$, A. Satta", G. Morici ${ }^{+, f}$, M.A. Vignola ${ }^{\S, f, \dagger}$ and \\ M.R. Bonsignore ${ }^{\S, f}$
}

ABSTRACT: Circulating CD34+ cells are haemopoietic progenitors that may play a role in tissue repair. No data are available on circulating progenitors in chronic obstructive pulmonary disease (COPD).

Circulating CD34+ cells were studied in 18 patients with moderate-to-severe COPD (age: mean \pm SD $68 \pm 8$ yrs; forced expiratory volume in one second: $48 \pm 12 \%$ predicted) and 12 controls, at rest and after endurance exercise. Plasma concentrations of haematopoietic growth factors (FMS-like tyrosine kinase 3 (Flt3) ligand, kit ligand), markers of hypoxia (vascular endothelial growth factor (VEGF)) and stimulators of angiogenesis (VEGF, hepatocyte growth factor (HGF)) and markers of systemic inflammation (tumour necrosis factor (TNF)- $\alpha$, interleukin (IL)-6, IL-8) were measured.

Compared with the controls, the COPD patients showed a three-fold reduction in CD34+ cell counts $\left(3.3 \pm 2.5\right.$ versus $10.3 \pm 4.2$ cells $\left.\mu \mathrm{L}^{-1}\right)$, and a $50 \%$ decrease in AC133+ cells. In the COPD patients, progenitor-derived haemopoietic and endothelial cell colonies were reduced by $30-50 \%$. However, four COPD patients showed progenitor counts in the normal range associated with lower TNF- $\alpha$ levels. In the entire sample, CD34+ cell counts correlated with exercise capacity and severity of airflow obstruction. After endurance exercise, progenitor counts were unchanged, while plasma FIt3 ligand and VEGF only increased in the COPD patients. Plasma HGF levels were higher in the COPD patients compared with the controls and correlated inversely with the number of progenitor-derived colonies.

In conclusion, circulating CD34+ cells and endothelial progenitors were decreased in chronic obstructive pulmonary disease patients and could be correlated with disease severity.

KEYWORDS: CD34+ cells, chronic obstructive pulmonary disease, exercise, growth factors, hypoxia

$\mathbf{T}$ he systemic effects of chronic obstructive pulmonary disease (COPD) have been studied with regards to inflammation, chronic oxidative stress and skeletal muscle dysfunction [1]. Despite evidence of neutrophils activation in peripheral blood of COPD patients [2], inflammatory infiltration of the airways in severe disease [3], and smoking-induced increase in granulocyte turnover, little is known about the effects of COPD at the level of bone marrow [4]. Data on the erythrocyte lineage have shown that anaemia occurs in $13 \%$ of COPD patients and is associated with increased inflammatory markers [5], and may predict poor survival [6]. Data on other blood lineages are scarce due to the need of invasive techniques to obtain bone marrow samples.

For editorial comments see page 441 .
This difficulty can be partly overcome by studying circulating bone marrow-derived progenitors. These cells are positive for CD34 and other markers (CD38, human leukocyte antigen (HLA)DR) acquired during differentiation [7], and yield indirect information on haemopoiesis. Circulating CD34+ cells are also believed to be involved in tissue repair. Bone marrow-derived progenitors can engraft in several organs including the lungs [8,9] and skeletal muscle [10]. The latter finding is of interest in COPD, given the frequent occurrence of skeletal muscle dysfunction associated with increased muscle apoptosis [11], fibrosis [12] and inflammatory activation [13].

At least part of the repair potential of CD34+ cells may depend on the AC133+ endothelial progenitor cell (EPC) subpopulation [14]. EPCs have been used to treat patients with myocardial [15]
AFFILIATIONS

*Dipartimento di Medicina Clinica,

University La Sapienza, and

\#Istituto Superiore di Sanita', Rome, and

'Fondazione Maugeri, Tradate, Varese, and

${ }^{+}$Dept of Experimental Medicine, and § Institute of Medicine and

Pneumology, University of Palermo, and

fIBIM-CNR, Palermo, Italy.

CORRESPONDENCE

P. Palange

Dipartimento di Medicina Clinica

University La Sapienza

Viale Università 37

Rome

00185 Italy

Fax: 39064940421

E-mail: paolo.palange@uniroma1.it

Received

October 222004

Accepted after revision:

October 152005

\section{SUPPORT STATEMENT}

The present study was funded by the Italian National Council of Research, Agenzia 2000 (CNRC005114), and the National Institute of Health (ISS), Rome. 
and vascular [16] disease. Low circulating EPC counts were found in patients with cardiovascular risk factors [17], and bone marrow CD34+ cells showed a low proliferative capacity in patients with chronic ischemic heart disease [18]. However, exercise training increased EPCs [19]. Whether COPD affects circulating EPCs and/or CD34+ cell proliferative capabilities is unknown.

Exercise might be a useful model to study circulating progenitors. Long-distance runners showed increased circulating

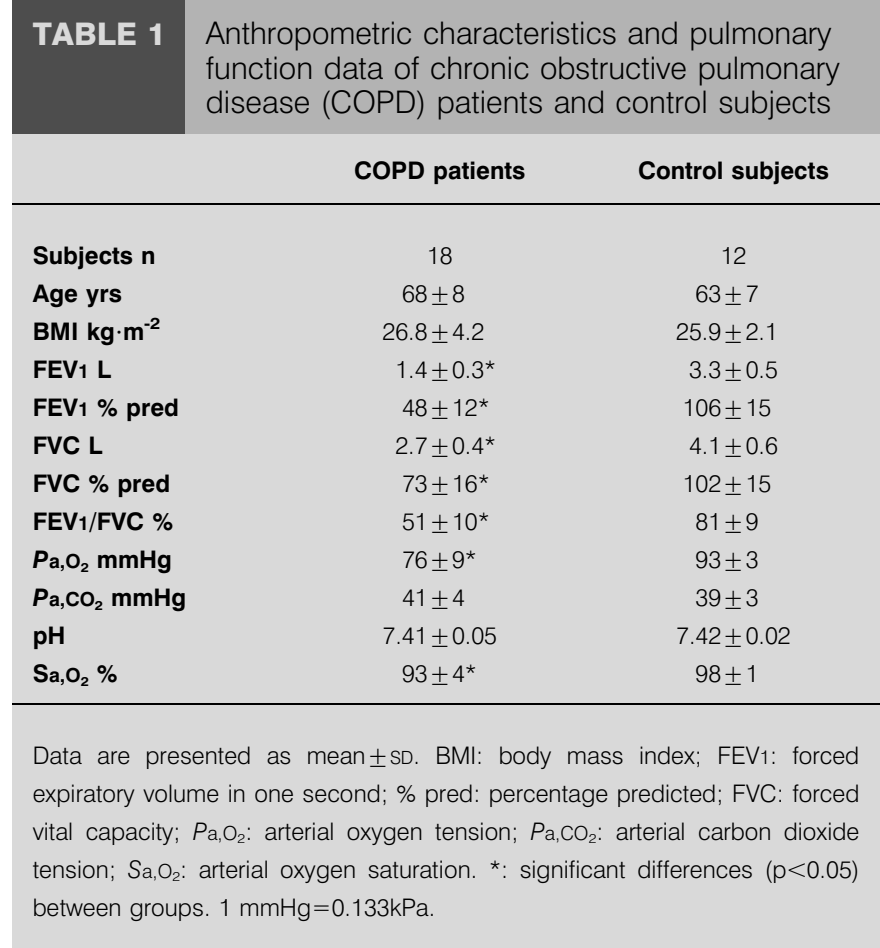

TABLE 2 Exercise data ${ }^{\#}$ in chronic obstructive pulmonary disease (COPD) patients and control subjects

\begin{tabular}{|c|c|c|}
\hline & COPD patients & Control subjects \\
\hline Load W & $92 \pm 15^{\star}$ & $133 \pm 18$ \\
\hline$V^{\prime} \mathrm{O}_{2}$ peak $L \cdot \mathrm{min}^{-1}$ & $1.53 \pm 0.24^{*}$ & $2.22 \pm 0.25$ \\
\hline$V^{\prime} \mathrm{O}_{2}$ peak $\mathrm{mL} \cdot \mathrm{kg}^{-1} \cdot \mathrm{min}^{-1}$ & $19.8 \pm 2.6^{*}$ & $28.5 \pm 4.0$ \\
\hline$V^{\prime} E$ peak L. $\min ^{-1}$ & $48.7 \pm 14.6^{*}$ & $62.5 \pm 5.6$ \\
\hline TV L & $1.6 \pm 0.3^{*}$ & $2.3 \pm 0.3$ \\
\hline Rf & $31.4 \pm 7.2$ & $28.9 \pm 6.1$ \\
\hline t। / t tot & $0.40 \pm 0.01^{\star}$ & $0.50 \pm 0.01$ \\
\hline RER & $1.00 \pm 0.1$ & $1.02 \pm 0.05$ \\
\hline$V^{\prime} \mathrm{E} / V^{\prime} \mathrm{CO}_{2}$ & $29.3 \pm 5.4$ & $25.4 \pm 1.7$ \\
\hline HR & $125.8 \pm 11.1^{*}$ & $138.6 \pm 15.4$ \\
\hline$V^{\prime} \mathrm{O}_{2}-\mathrm{LT} L \cdot \mathrm{min}^{-1}$ & $1.07 \pm 0.23^{\star}$ & $1.45 \pm 0.25$ \\
\hline$V^{\prime} \mathrm{O}_{2}-\mathrm{LT} / V^{\prime} \mathrm{O}_{2}$ peak & $0.55 \pm 0.13^{*}$ & $0.66 \pm 0.11$ \\
\hline
\end{tabular}

Data are presented as mean $\pm \mathrm{SD}$. W: Watt; $\mathrm{V}^{\prime} \mathrm{O}_{2}$ : oxygen uptake; $V^{\prime} \mathrm{E}$ : minute ventilation; TV: tidal volume; Rf: respiratory frequency, breaths per minute; $t \mathrm{l} /$ tot: inspiratory time/total respiratory time; RER: respiratory exchange ratio; $V^{\prime} \mathrm{CO}_{2}$ : carbon dioxide output; $\mathrm{HR}$ : heart rate, beats per minute; LT: lactic threshold. \#: maximal incremental test. *: significant difference $(p<0.05)$ between groups.
TABLE 3 Blood cell counts in control subjects and in chronic obstructive disease (COPD) patients at baseline $(\mathrm{BL})$ and after endurance exercise (Exe)

\begin{tabular}{|c|c|c|c|c|}
\hline & \multicolumn{2}{|c|}{ COPD patients } & \multicolumn{2}{|c|}{ Control subjects } \\
\hline & BL & Exe & BL & Exe \\
\hline RBC $10^{6} \cdot \mu \mathrm{L}^{-1}$ & $5.00 \pm 0.51$ & $5.07 \pm 0.57$ & $4.87 \pm 0.35$ & $4.93 \pm 0.40$ \\
\hline $\mathrm{Hb} \mathbf{g} \cdot \mathrm{dL}^{-1}$ & $14.7 \pm 1.3$ & $15.1 \pm 1.1$ & $14.9 \pm 1.0$ & $15.0 \pm 1.1$ \\
\hline WBC $10^{3} \cdot \mu \mathrm{L}^{-1}$ & $6.96 \pm 1.31$ & $7.73 \pm 1.64$ & $6.14 \pm 1.27$ & $6.62 \pm 1.67$ \\
\hline Neutrophils \% & $64.8 \pm 6.1^{*}$ & $63.0 \pm 7.3$ & $57.0 \pm 6.9$ & $58.6 \pm 7.3$ \\
\hline Lymphocytes \% & $23.2 \pm 5.7^{\star}$ & $25.5 \pm 6.7$ & $31.6 \pm 7.4$ & $29.7 \pm 8.1$ \\
\hline Monocytes \% & $6.5 \pm 1.4$ & $5.9 \pm 0.8$ & $6.2 \pm 1.0$ & $6.0 \pm 1.1$ \\
\hline Eosinophils \% & $2.8 \pm 1.6$ & $2.7 \pm 1.3$ & $2.6 \pm 1.3$ & $2.4 \pm 1.3$ \\
\hline Basophils \% & $0.6 \pm 0.3$ & $0.7 \pm 0.3$ & $0.7 \pm 0.2$ & $0.7 \pm 0.2$ \\
\hline $\begin{array}{l}\text { Platelets } \\
\qquad 10^{5} \cdot \mu \mathrm{L}^{-1}\end{array}$ & $234 \pm 73$ & $253 \pm 74$ & $199 \pm 45$ & $216 \pm 35$ \\
\hline
\end{tabular}

Data presented as mean $\pm S D$. RBC: red blood cells: Hb: haemoglobin; WBC: white blood cells. *: significant difference $(p<0.05)$ between resting values in COPD patients and controls (unpaired t-test).
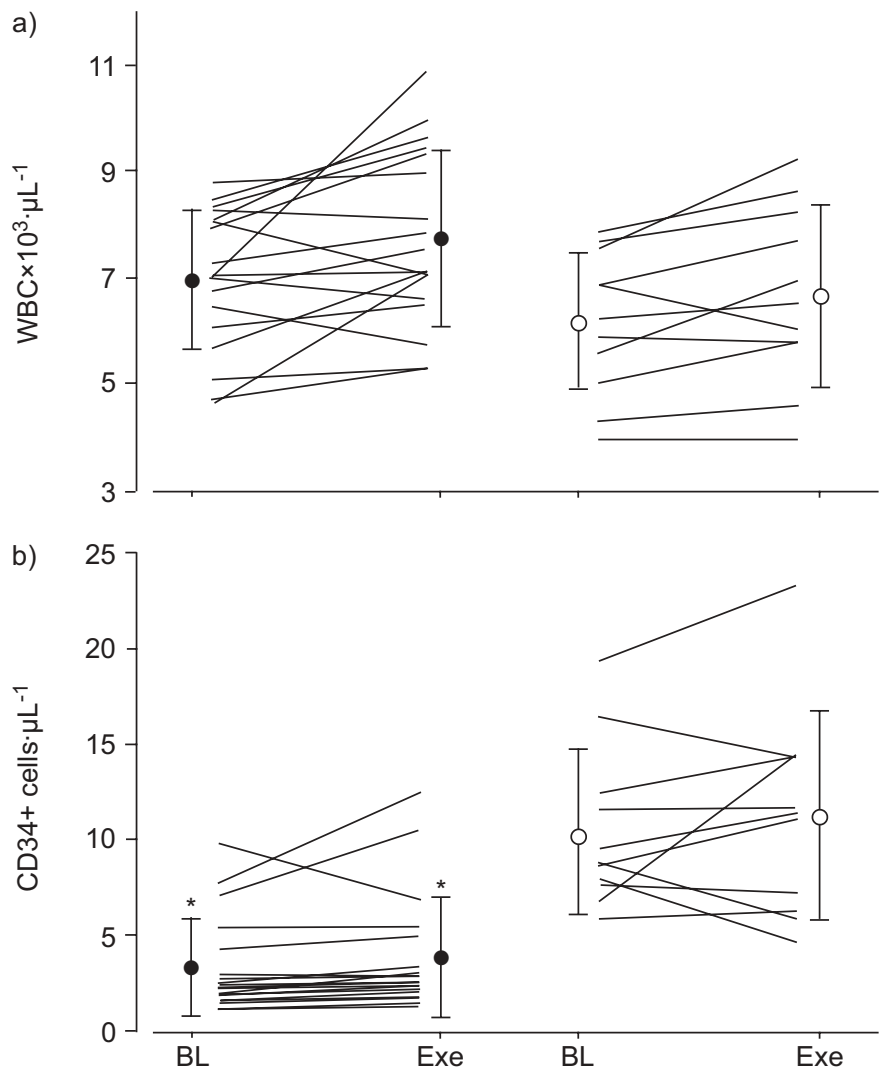

FIGURE 1. a) White blood cells (WBC) and b) CD34+ cells at baseline (BL) and after endurance exercise (Exe) in chronic obstructive pulmonary disease (COPD) patients $(\bullet)$ and in control subjects $(O)$. Note the marked uniform reduction in CD34+ cells in COPD patients compared with the control subjects. ${ }^{*}: p<0.001$, COPD versus controls. 
CD34+ cells and exercise-induced release of factors/cytokines active on the bone marrow (FMS-like tyrosine kinase 3 (Flt3) ligand, interleukin (IL)-6, granulocyte colony-stimulating factor (G-CSF), tumour necrosis factor (TNF)- $\alpha$ ) [20, 21] Mobilisation of endothelial progenitor cells also occurred after exercise in middle-aged untrained subjects [22], but little is known on the relationship between circulating progenitors and exercise limitation in COPD, or on the effects of inflammatory activation on progenitors.

Finally, COPD may affect haemopoietic and endothelial progenitors through alterations in arterial blood gases or inflammatory mediators. In vitro, very low arterial oxygen tension preserved early haemopoietic progenitors [23], while promoting their differentiation [24]. No study addressed the effects of mild hypoxaemia on circulating CD34+ cells and subpopulations in vivo in COPD patients.

The present study was designed to answer whether or not COPD affects circulating progenitor cell numbers and frequency.

\section{SUBJECTS AND METHODS}

In total, 18 ex-smokers with COPD and 12 age-matched nonsmokers (controls) were studied (table 1). Inclusion criteria for patients were: 1) COPD of moderate severity (Global Initiative for Chronic Obstructive Lung Disease stage 2); 2) stable clinical conditions (i.e. no change in pulmonary function tests or exacerbation in the 4 weeks preceding the study); and 3) mild, resting hypoxaemia (arterial oxygen tension: $\mathrm{Pa}, \mathrm{O}_{2}$ $>7.89 \mathrm{kPa}$ ). No patient was receiving systemic steroids at the time of the study. Inclusion criteria for controls were: 1) age $\geqslant 50 \mathrm{yrs}$; 2) a sedentary lifestyle; 3) normal spirometry and arterial blood gases; 4) no other clinically evident disease; and 5) a wish to participate in the study. Patients with cardiovascular, cerebrovascular, neuromuscular, rheumatological and/or metabolic disorders, as assessed by clinical and standard laboratory findings tests, were excluded from the studies. Patients were also excluded if they suffered from any disease precluding execution of exercise tests.

The protocol was approved by the Ethical Committee of the University of Rome (Italy), and all subjects gave their informed consent.

\section{Study protocol}

Each subject visited the laboratory three times. At the first visit, a complete clinical assessment and pulmonary function tests
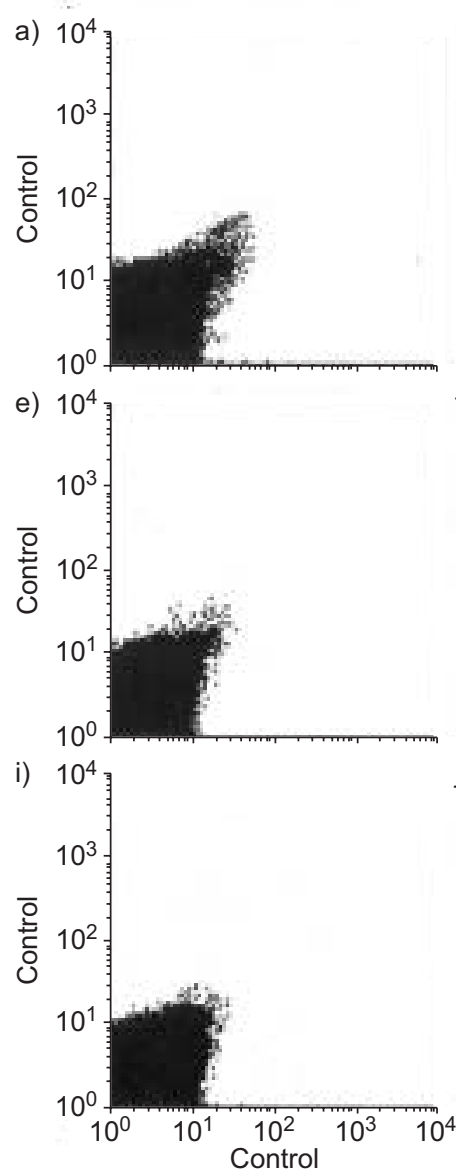
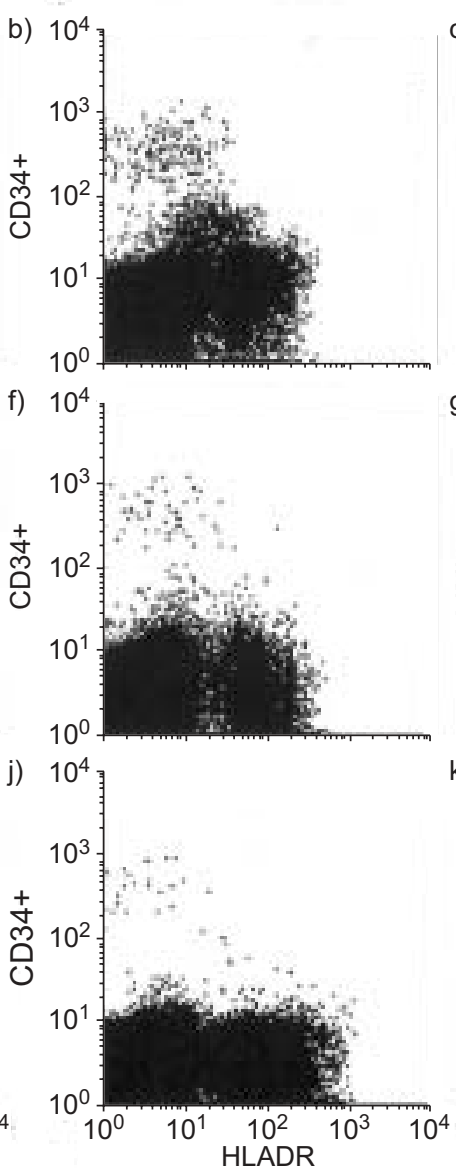

c) 10

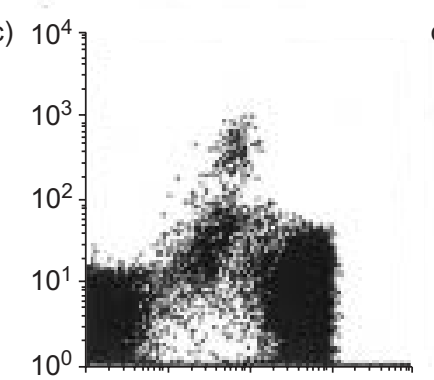

g) 10
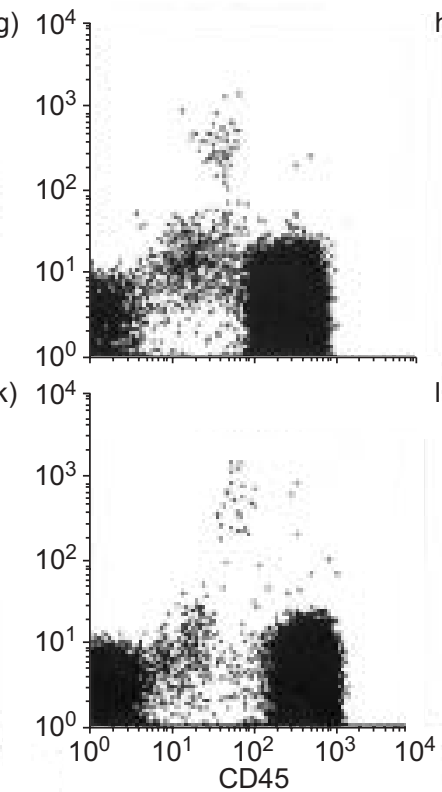

d) 10

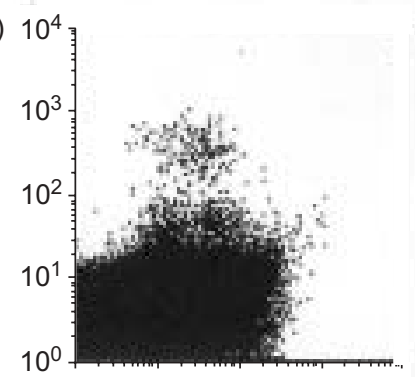

h) $10^{4}$

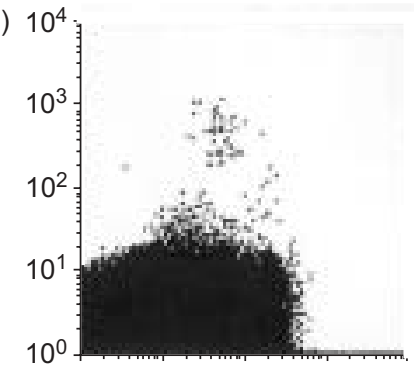

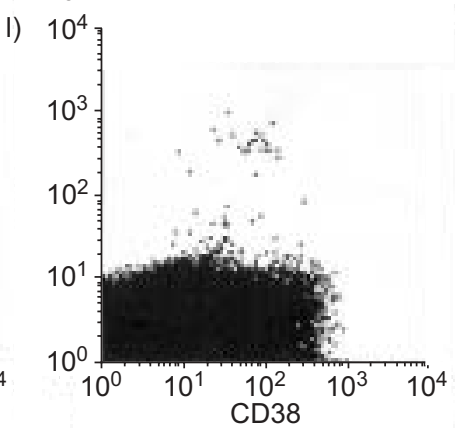

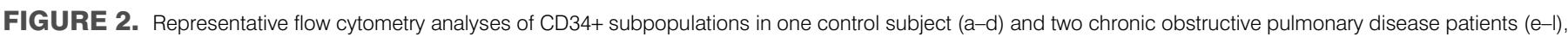

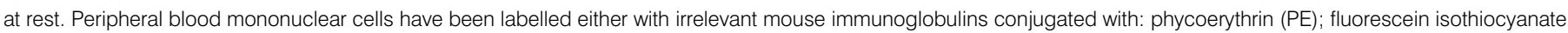

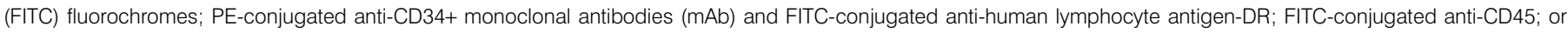
FITC-conjugated anti-CD38 mAb. 
(Quark PFT; COSMED, Rome, Italy) were obtained. A sample was drawn from the radial artery for arterial blood gas determination at rest while breathing room air. At the second visit each subject underwent an incremental exercise stress test on the cycle ergometer (Ergoline 800, Bitz, Germany) to determine peak oxygen uptake $\left(V^{\prime} \mathrm{O}_{2}\right.$ peak) and lactic threshold. Pulmonary gas exchange indexes were measured breath-bybreath by a computerised system as previously described [25]. Oxygen uptake $\left(V^{\prime} \mathrm{O}_{2} ;\right.$ at standard temperature and pressure, dry (STPD)), $\mathrm{CO}_{2}$ output $\left(V^{\prime} \mathrm{CO}_{2} ; \mathrm{STPD}\right)$, minute ventilation $\left(V^{\prime} \mathrm{E}\right.$; at body temperature and pressure, saturated with water vapour) and respiratory frequency were measured. Heart rate (HR) was derived from R-R intervals measured from a 12-lead ECG. At the third visit, each subject performed a submaximal exercise test on a cycle ergometer at a work-rate corresponding to $70 \%$ of $V^{\prime} \mathrm{O}_{2}$ peak for $20 \mathrm{~min}$ (endurance test). Exercise sessions were planned a minimum of $48 \mathrm{~h}$ apart. All tests were obtained while the subjects breathed room air.

Venous blood samples $(20 \mathrm{~mL})$ were drawn before and immediately after the endurance test for analysis of blood cell counts and CD34+ cells. Total blood cell counts were determined by standard haemocytometry. Peripheral blood mononuclear cells (PBMCs) were obtained by standard Ficoll gradient centrifugation. The cells were carefully washed with PBS, resuspended in PBS containing $2 \mathrm{mg} \cdot \mathrm{mL}^{-1}$ bovine serum albumin and labelled for $30 \mathrm{~min}$ at $4^{\circ} \mathrm{C}$ with the following antibodies: 1) anti-CD34 conjugated with phycoerythrin (PE); 2) anti-CD38; or 3) anti-HLA-DR, all labelled with fluoresceine isothiocyanate (FITC; Becton Dickinson-Pharmingen, Lincoln Park, NJ, USA). In some experiments PBMCs were labelled with anti-CD34 (FITC-conjugated) and either anti-very late activation antigen (VLA)-4 or anti-Flt3 (both PE-conjugated). For a negative control, the cells were labelled with isotypematched mouse immunoglobulin labelled with either PE or FITC. After two washings in cold PBS, the cells were analysed for fluorescence in a fluorescence-activated cell sorter flow cytometer (Becton-Dickinson). The level of positivity of entire body was evaluated as "dim" or "bright" according to the fluorescence labelling intensity. CD34+ cells and their subpopulations were expressed as percentage of total PBMCs. In some experiments PBMCs were labelled with PE-conjugated anti-AC133 monoclonal antibodies (Miltenyi Biotech, Bergisch Gladbach, Germany).
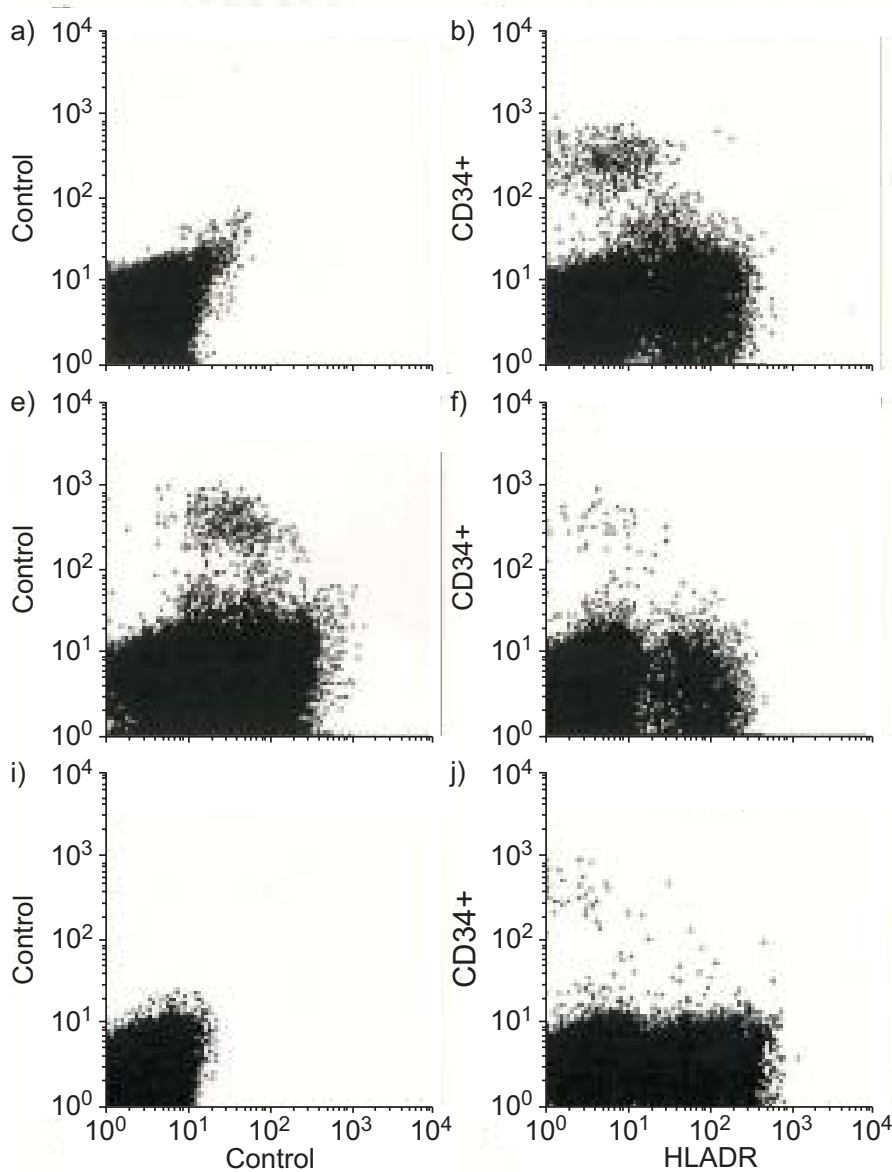
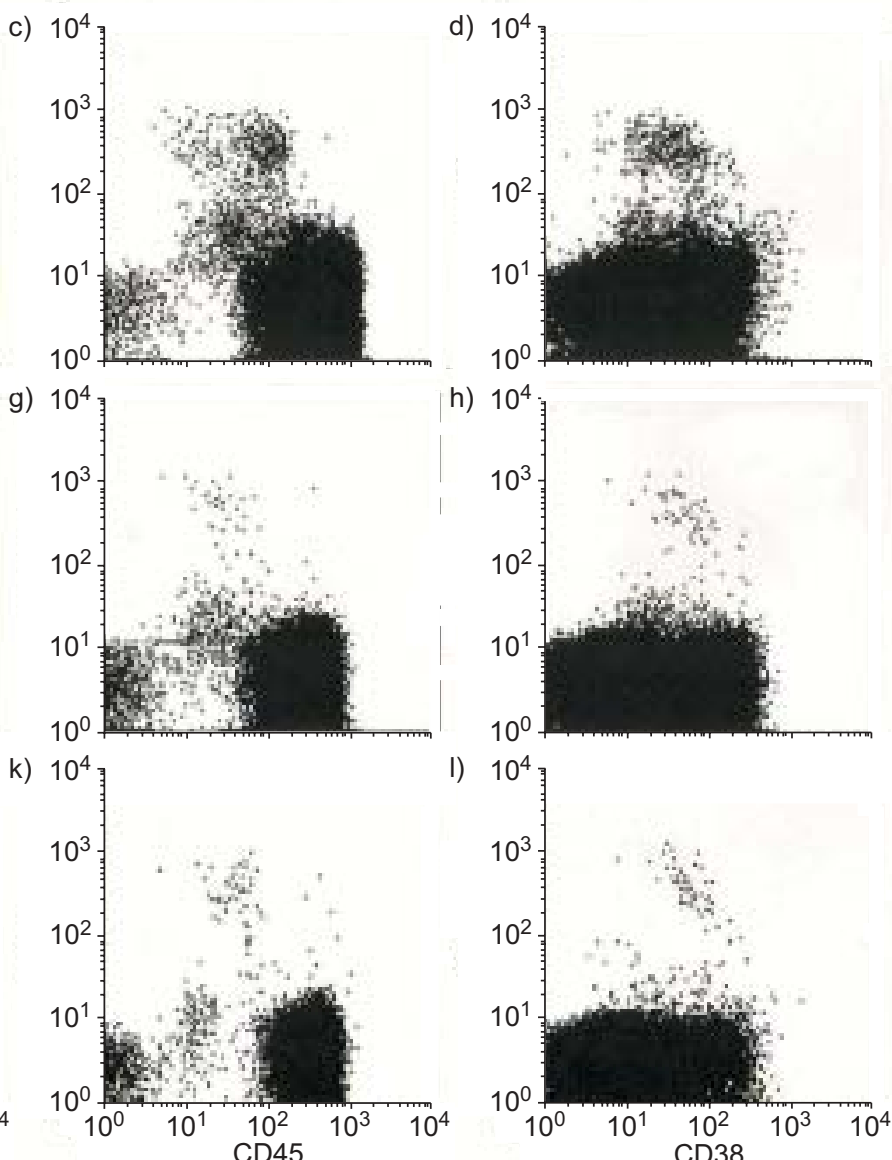

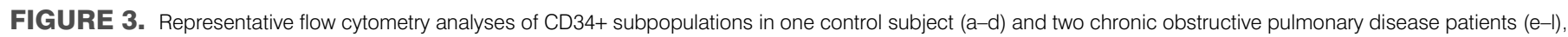



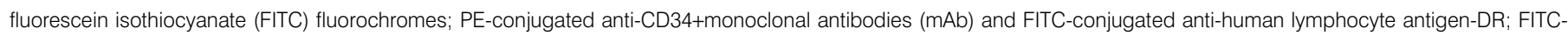
conjugated anti-CD45; or FITC-conjugated anti-CD38 mAb. 
Flow cytometry analysis was carried out using software gating on lymphocytes. At least $10^{5}$ gated events were acquired for each determination.

For the colony forming unit (CFU) assay, PBMCs were seeded at $3 \times 10^{5}$ cells $\cdot \mathrm{mL}^{-1} \cdot \mathrm{dish}^{-1}$ (Falcon 1008 ; Becton Dickinson) in $0.9 \%$ methylcellulose and $40 \%$ foetal calf serum (Gibco, Grand Island, NY, USA) in Iscove's modified Dulbecco's medium (Gibco), which was supplemented with $1.5 \mathrm{IU} \cdot \mathrm{mL}^{-1}$ erythropoietin for erythrocyte burst-forming units (E-BFU) colonies and $10 \mathrm{ng} \cdot \mathrm{mL}^{-1}$ of both granulocyte-monocyte colonystimulating factor and G-CSF for granulocyte-monocyte CFU (GM-CFU) colonies. Colonies were counted under an inverted microscope after 14-16 days of culture.

For endothelial progenitor colony assay, PBMCs were resuspended in EndoCult ${ }^{\mathrm{TM}}$ liquid medium (Stem Cell Technologies, Vancouver, BC, Canada) and plated $\left(5 \times 10^{6}\right.$ cells $)$ on fibronectin-coated 6-well dishes. After 2 days of culture at $37^{\circ} \mathrm{C}$, nonadherent cells were collected and $1 \times 10^{6}$ cells $^{\circ}$ well ${ }^{-1}$ were plated in duplicate on fibronectin-coated 24-well dishes. After 3-5 additional days of culture, endothelial cell CFUs (EC$\mathrm{CFU})$ were counted under an inverted microscope.

\section{Biochemical analyses}

These assays were performed in 17 COPD patients and six control subjects. Aliquots of serum were prepared and stored at $-80^{\circ} \mathrm{C}$ for determination by immunoassay (ELISA, R\&D Systems, Minneapolis, MN, USA) of the following. 1) Flt3 ligand and kit ligand (KL), both acting on early haemopoietic stages (detection limit: $5.0 \mathrm{pg} \cdot \mathrm{mL}^{-1}$ for both) [26]. 2) Vascular endothelial growth factor (VEGF), as a marker of tissue hypoxia and angiogenesis (detection limit: $5.0 \mathrm{pg} \cdot \mathrm{mL}^{-1}$ ) [27]. 3) Hepatocyte growth factor (HGF), a mediator known to activate proliferation and migration of endothelial cells and induce angiogenesis [28] (detection limit: $20 \mathrm{pg} \cdot \mathrm{mL}^{-1}$ ). 4) TNF$\alpha$ (detection limit $0.2 \mathrm{pg} \cdot \mathrm{mL}^{-1}$ ), and IL-8 (detection limit: $\left.0.2 \mathrm{pg} \cdot \mathrm{mL}^{-1}\right)$ as markers of systemic inflammation. As well as IL-6 (detection limit: $0.16 \mathrm{pg} \cdot \mathrm{mL}^{-1}$ ), which is known to be released during prolonged exercise [29]. The serum concentration of cortisol and muscle enzymes (lactic dehydrogenase, creatine phosphokinase) as markers of muscle damage was determined using standard methods.

\section{Statistics}

Data are expressed as means $\pm S D$. ANOVA and t-test or Wilcoxon test were used to compare experimental conditions. Paired t-tests were used in each group to compare baseline and post-exercise data. Unpaired t-tests were used to compare the COPD and control groups. When data appeared to be abnormally distributed, Wilcoxon or Mann-Whitney U-tests were used for paired or unpaired comparisons, respectively. Linear regression was used to assess relationships between variables. The level of significance was set at $\mathrm{p}<0.05$.

\section{RESULTS}

\section{Subjects and functional data}

Table 1 summarises anthropometric and pulmonary function data and arterial blood gas measurements. COPD patients showed moderate-to-severe functional deterioration. During maximal exercise stress test (table 2) COPD patients attained lower $V^{\prime} \mathrm{O}_{2}, V^{\prime} \mathrm{E}$ and $\mathrm{HR}$ at peak exercise than controls.

\section{Endurance test}

Mean \pm SD workload was $133 \pm 18 \mathrm{~W}$ in controls, and $92 \pm 15 \mathrm{~W}$ in COPD patients $(\mathrm{p}<0.001$ by unpaired $\mathrm{t}$-test). All normal subjects and 17 COPD patients completed the 20-min exercise test. One patient stopped at $10 \mathrm{~min}$ because of intolerable dyspnoea.

Red blood cells and platelet counts were similar in the control subjects and COPD patients, both pre- and post-exercise (table 3). A slightly anaemic state (haemoglobin concentration $<13.5 \mathrm{mg} \cdot \mathrm{dL}^{-1}$ ) was found in one COPD patient and one control subject.

White blood cell (WBC) counts were in the normal range in both groups. However, COPD patients showed slightly higher WBC (fig. 1a) and neutrophil differential counts compared with controls at baseline (table 3). The latter difference between groups was not found in the post-exercise samples.

\section{Circulating CD34+ cells, clonogenetic assays and haemopoietic growth factors}

Circulating CD34 ${ }^{+}$cells as the percentage of lymphocytes were approximately three times lower in the COPD patients when compared with the normal subjects at rest $(0.22 \pm 0.19$ versus $0.57 \pm 0.26 \%$ ), and were unaffected by endurance exercise in either group (COPD: $0.21 \pm 0.16 \%$; controls: $0.61 \pm 0.28 \%$ ). These differences were of the same magnitude when CD34+ cells were expressed as absolute numbers per $\mu \mathrm{L}$ blood volume, both at rest $(3.3 \pm 2.5$ versus $10.3 \pm 4.2 ; \mathrm{p}<0.001)$ and after endurance exercise $(3.8 \pm 3.1$ versus $11.2 \pm 5.4 ; \mathrm{p}<0.001$; fig. 1b). In addition, double labelling experiments with antiCD34 and anti-CD38 or anti-HLA-DR monoclonal antibodies have been performed to allow the identification of immature (34+/38- and 34+/HLA-DR-) and mature (34+/38+ and 34+/ HLA-DR+) haemopoietic progenitors [7]. CD34+ cell subpopulations (34+/38-, 34+/38+, 34+/HLA-D-, 34+/HLA-DR+) were uniformly decreased in COPD patients compared with

\begin{tabular}{|c|c|c|c|c|}
\hline \multirow[t]{3}{*}{ TABLE 4} & \multicolumn{4}{|c|}{$\begin{array}{l}\text { CD34+ subpopulations }{ }^{\#} \text { in control subjects and } \\
\text { in chronic obstructive pulmonary disease } \\
\text { patients (COPD) at baseline (BL) and after } \\
\text { endurance exercise (Exe) }\end{array}$} \\
\hline & \multicolumn{2}{|c|}{ COPD Patients } & \multicolumn{2}{|c|}{ Normal Subjects } \\
\hline & BL & Exe & BL & Exe \\
\hline $\mathrm{CD}^{+} 4^{+} \mathrm{CD}^{-} 8^{-}$ & $0.37 \pm 0.63$ & $0.57 \pm 0.07$ & $1.77 \pm 0.93$ & $2.10 \pm 0.60$ \\
\hline $\mathrm{CD} 4^{+} \mathrm{CD} 8^{+}$ & $3.12 \pm 2.82$ & $3.90 \pm 3.07$ & $8.72 \pm 3.90$ & $9.49 \pm 4.21$ \\
\hline CD34 $^{+}$HLA-DR $^{-}$ & $3.14 \pm 3.08$ & $4.20 \pm 3.50$ & $8.85 \pm 4.18$ & $10.10 \pm 5.10$ \\
\hline CD34 $^{+}$HLA-DR $^{+}$ & $0.36 \pm 0.20$ & $0.40 \pm 0.26$ & $1.50 \pm 1.10$ & $1.93 \pm 0.96$ \\
\hline CD34 $^{+}$VLA-4 - & $0.15 \pm 0.14$ & $0.31 \pm 0.24$ & $0.36 \pm 0.31$ & $0.31 \pm 0.35$ \\
\hline CD34 $^{+}$VLA-4 ${ }^{+}$ & $3.35 \pm 2.60$ & $4.21 \pm 3.06$ & $10.10 \pm 8.40$ & $11.70 \pm 6.40$ \\
\hline $\mathrm{CD}^{+} 4^{+} \mathrm{CXCR}^{-}$ & $2.06 \pm 1.92$ & $2.79 \pm 1.36$ & $7.15 \pm 3.70$ & $7.90 \pm 5.10$ \\
\hline $\mathrm{CD} 4^{+} \mathrm{CXCR4}^{+}$ & $1.43 \pm 1.10$ & $1.71 \pm 1.44$ & $3.46 \pm 3.55$ & $4.10 \pm 2.20$ \\
\hline
\end{tabular}

Data are presented as mean \pm SD. HLA-DR: human leukocyte antigen-DR; VLA-4: very late activation antigen-4; CXCR: C-X-C motif chemokine receptor 4 . Analysis by ANOVA showed a significant difference between COPD and control groups for all subpopulation ( $p<0.005$ for all comparisons), but no difference between baseline and post-exercise data. ${ }^{\#}$ : expressed as number per $\mathrm{mL}$ of blood. 

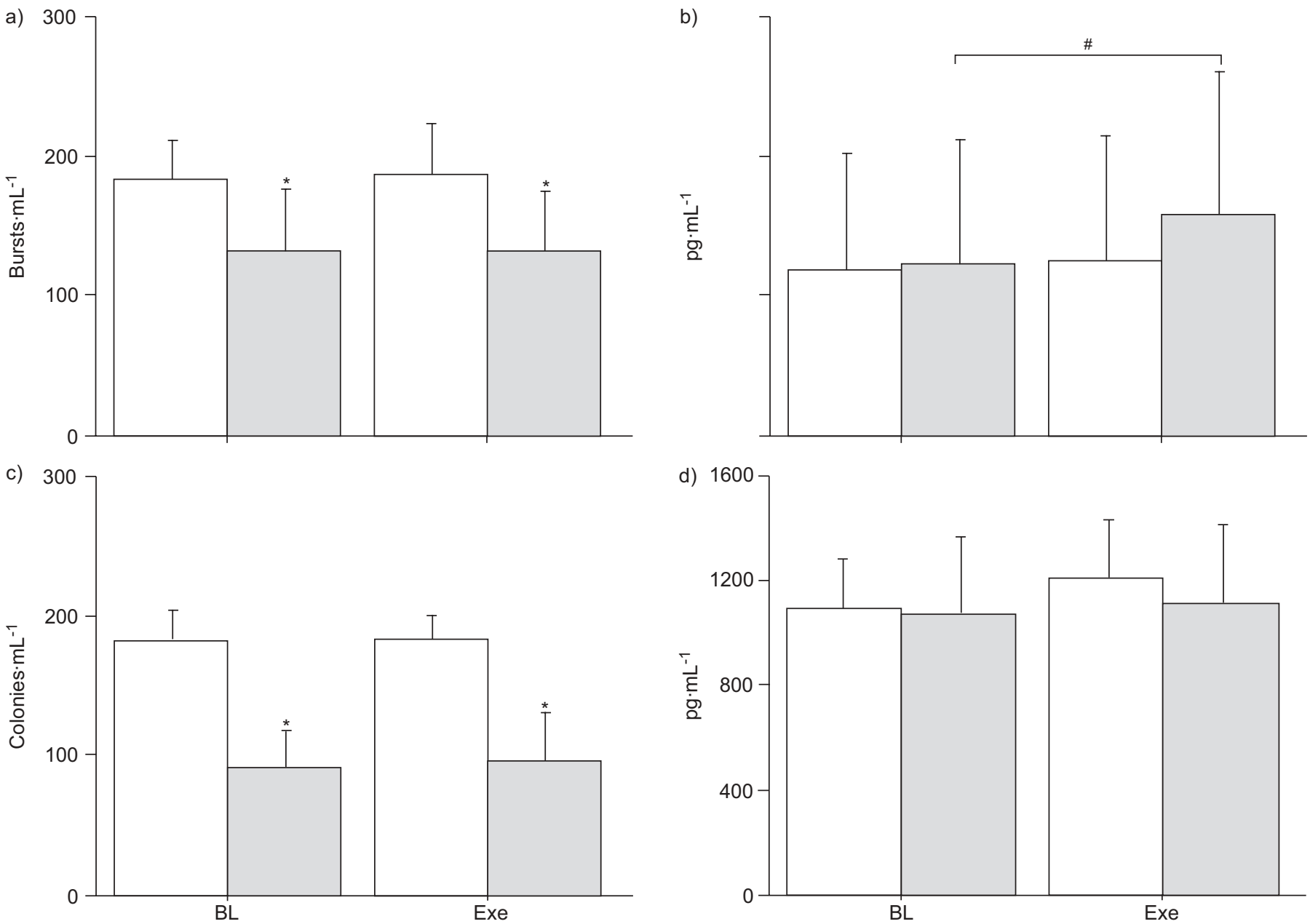

FIGURE 4. a) Erythrocyte burst forming units E-BFU; b) plasma Flt3 ligand; c) granulocyte-monocyte colony-forming units (GM-CFU); and d) plasma kit ligand, at baseline (BL) and after endurance exercise (Exe) in chronic obstructive pulmonary disease (COPD) patients ( $\square$ ) and in control subjects $(\square)$. Note the marked reduction in EBFU and GM-CFU in COPD patients at BL and after Exe compared with normal subjects. *: $p<0.05$ COPD versus controls; ${ }^{*}$ : $p<0.05$ Exe versus BL.

the controls (figs 2, 3; table 4). The endurance exercise did not change the number of circulating CD34+ cells (fig. 4; table 4).

In some COPD patients ( $n=4,22 \%$ of the sample) CD34+ cell counts were in the normal range $(0.56 \pm 0.14 \%$ of lymphocytes) as opposed to the mean value of $0.12 \pm 0.03 \%$ in the rest of the COPD group $(n=14)$. The patients with normal CD34+ cell counts could not be identified based on anthropometric characteristics or COPD severity. They only showed a trend towards a higher $V^{\prime} \mathrm{O}_{2}$ peak $(21.5 \pm 3.1$ versus $18.9 \pm 2.1 \mathrm{~mL}$. $\mathrm{kg}^{-1} \cdot \mathrm{min}^{-1} ; \mathrm{p}=0.07$ ) and lower plasma TNF- $\alpha$ levels (rest: $1.78 \pm 0.79$ versus $2.30 \pm 1.22 \mathrm{pg} \cdot \mathrm{mL}^{-1}$; post-exercise: $1.11 \pm 0.11$ versus $\left.1.96 \pm 0.77 \mathrm{pg} \cdot \mathrm{mL}^{-1}, \mathrm{p}<0.05\right)$.

Given the decrease in the number of circulating CD34+ cells in COPD patients, the current authors evaluated whether the number of circulating haemopoietic progenitor cells, as measured by standard clonogenetic assays, were correspondingly decreased. COPD patients displayed a significantly reduced number of CFUs compared with the controls (fig. $4 \mathrm{a}$ and $4 \mathrm{c}$ ). In both groups, E-BFU and GM-CFU numbers, after endurance exercise, were similar to those observed at rest (fig. $4 \mathrm{a}$ and $4 \mathrm{c}$ ). It is of interest to note that the majority of
COPD patients displayed not only a reduced colony number, but also smaller E-BFU and GM-CFU compared with the controls (fig. 5). In figure 5 the representative pictures of individual E-BFU and GM-CFU colonies derived from the blood of a control subject (fig. 5c), a COPD patient with a normal CD34+ cell count (fig. 5b) and a COPD patient with a low $\mathrm{CD} 4^{+}$cell count (fig. 5a) are shown. The size of individual E-BFU colonies (each included in a separate box) and of GMCFU colonies are smaller in COPD patients with low CD34 ${ }^{+}$ cell counts (fig. 5a, observe the three individual E-BFUs and the two GM-CFU colonies), compared with those observed for E-BFU and GM-CFU colonies derived from normal controls (fig. 5c) or COPD patients with normal $\mathrm{CD}^{+}$cell count (fig. 5b).

Given the reduced number of circulating haemopoietic progenitors in COPD, the current authors evaluated the plasma concentration of several cytokines normally involved in the survival and proliferation of haemopoietic progenitors. In this context, the current authors' focused on the Flt3 ligand and KL. Flt3 ligand expression on CD34+ cell surface did not differ between COPD patients and controls (data not shown). Plasma Flt3 ligand concentration was similar in COPD patients 
a)

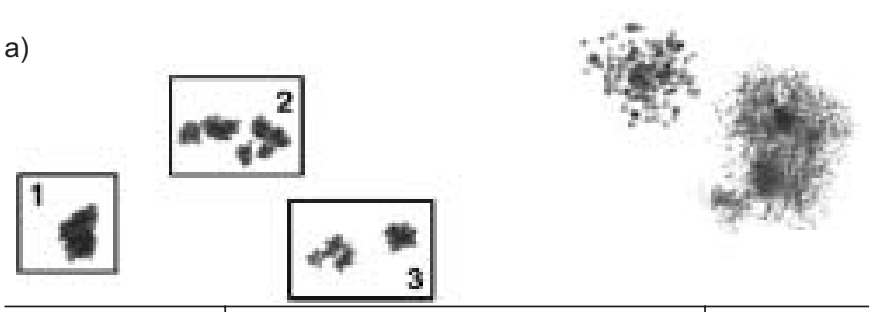

b)



c)

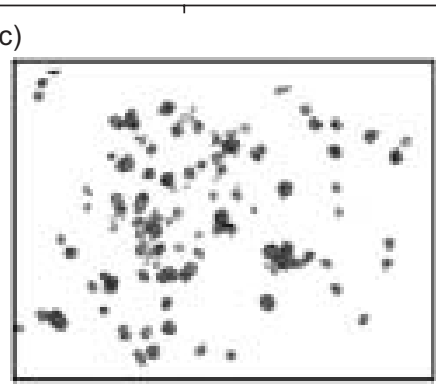

E-BFU



Poser.

GM-CFU

FIGURE 5. Representative pictures of single colonies of erythrocyte burst forming units (E-BFU) and granulocyte-monocyte colony-forming units (GM-CFU) obtained in clonogenetic culture from the following. a) A chronic obstructive pulmonary disease (COPD) patient with a low CD34+ cell count. b) A COPD patient with a normal CD34+ cell count. C) A control subject. For E-BFU each box represents an individual E-BFU colony, therefore, the E-BFU colonies from the COPD patient with low CD34+ cells (a) are markedly smaller than those observed in controls (c) or in a COPD patient with normal CD34+ cell count (b).

and controls at baseline; it increased significantly after endurance exercise in COPD patients only (fig. 4b). Plasma KL levels, did not differ between groups or experimental conditions (fig. $4 \mathrm{~d}$ ).

In the entire group of subjects studied (i.e. COPD patients and controls) circulating CD34+ cell counts correlated directly with $V^{\prime} \mathrm{O}_{2}$ peak (fig 6d; $\left.\mathrm{r}^{2}=0.37, \mathrm{p}<0.05\right)$, resting $\mathrm{Pa}_{1} \mathrm{O}_{2}\left(6 \mathrm{a} ; \mathrm{r}^{2}=0.30\right.$, $\mathrm{p}<0.05)$ and with the severity of airway obstruction assessed as forced expiratory volume in one second (FEV1)/forced vital capacity $\left(6 \mathrm{c} ; \mathrm{r}^{2}=0.39 ; \mathrm{p}<0.05\right)$. No correlation was found between CD34+ cell counts and carbon dioxide arterial tension (fig. 6b). The $\mathrm{r}^{2}$ values were calculated for the entire group of subjects studied (i.e. COPD patients and controls combined).

\section{Circulating AC133+ cells, endothelial cell progenitors and angiogenetic growth factors}

Circulating AC133+ cells, in COPD patients at rest, were approximately half the value found in control subjects and were unaffected by endurance exercise in either group (fig. 7a). The decrease in AC133+ cells was also evident when expressed as absolute cell count per $\mu \mathrm{L}$ of blood volume both at rest (COPD: $2.5 \pm 1.7$ cells $\cdot \mu \mathrm{L}^{-1}$; control: $6.1 \pm 3.0$ ) and after

endurance exercise (COPD: $2.7 \pm 1.8$ cells $\cdot \mu \mathrm{L}^{-1}$; control: $6.5 \pm 3.1$ cells $\left.\cdot \mu \mathrm{L}^{-1}\right)$. Weak but significant direct relationships were found in the entire group between baseline AC133+ cell counts and $\mathrm{Pa}_{1} \mathrm{O}_{2}\left(\mathrm{r}^{2}=0.21, \mathrm{p}<0.05\right), \mathrm{FEV} 1\left(\mathrm{r}^{2}=0.19, \mathrm{p}<0.05\right)$ and the fitness level expressed as maximal load in $\mathrm{W}\left(\mathrm{r}^{2}=0.236\right.$, $\mathrm{p}<0.05)$.

A consistent decrease in the number of circulating endothelial progenitors per $\mathrm{mL}$ of blood in COPD patients was also found. A specific clonogenic assay showed that their number was significantly decreased in COPD patients at rest (COPD patients: $18.2 \pm 7.2 \mathrm{EC}-\mathrm{CFU} \cdot \mathrm{mL}^{-1}$ of blood; control subjects: $30 \pm 4$ EC-CFU $\cdot \mathrm{mL}^{-1}$ of blood) and after exercise (COPD patients: $20.1 \pm 8.4 \mathrm{CFU}-\mathrm{EC} \cdot \mathrm{mL}^{-1}$ of blood; control subjects: $32.2 \pm 8.2 \mathrm{EC}-\mathrm{CFU} \cdot \mathrm{mL}^{-1}$ of blood; fig. $7 \mathrm{c}$ ).

As for changes in plasma concentration of endothelial growth factors, VEGF and HGF showed some marked and interesting differences (fig. $7 \mathrm{~b}$ and $\mathrm{d}$ ). Plasma VEGF concentration was higher in COPD patients than in control subjects at rest (COPD patients: $69 \pm 68 \mathrm{pg} \cdot \mathrm{mL}^{-1}$; control subjects: $\left.26 \pm 8 \mathrm{pg} \cdot \mathrm{mL}^{-1}\right)$, and increased further after exercise (COPD patients: $201 \pm 205 \mathrm{pg} \cdot \mathrm{mL}^{-1}$; control subjects: $\left.27 \pm 2 \mathrm{pg} \cdot \mathrm{mL}^{-1}\right)$. Plasma HGF levels at rest were higher in COPD patients when compared with the control subjects, but remained unchanged in either group after exercise (fig. 7d). HGF, but not VEGF, levels correlated inversely with the results of clonogenetic tests (fig. 8).

\section{Other biochemical measurements}

Muscle enzymes (lactate dehydrogenase and creative kinase) and cortisol levels were similar in COPD patients and control subjects and remained unchanged in post-exercise samples (table 5). Plasma TNF- $\alpha$ concentration did not differ significantly between COPD and control groups, even though some differences were found between COPD patients with normal and low CD34+ cell counts as reported previously in the results section.

Plasma IL-6 levels were increased in COPD patients compared with controls $(p<0.01$ by ANOVA; table 5$)$. IL- 8 values did not differ significantly between groups but showed a large dispersion, with some COPD patients showing very high plasma concentrations at rest.

\section{DISCUSSION}

In COPD patients with moderate-to-severe respiratory impairment, blood cell counts were normal while circulating haemopoietic and endothelial progenitor counts were greatly decreased, when compared with control subjects. The number of progenitor-derived colonies was correspondingly low $(-30--50 \%)$ in the COPD group. However, $\sim 20 \%$ of COPD patients, clinically and functionally similar to the rest of the group, showed normal progenitor counts associated with less inflammatory activity as estimated by plasma TNF- $\alpha$ concentrations. Endurance exercise did not affect circulating CD34+ cells in either COPD patients or control subjects. The postexercise increase in plasma VEGF suggested activation of the hypoxic pathway in COPD patients, but not in the control subjects. The endurance exercise in COPD patients appears to make the initial hypoxic condition, observed at rest, more severe and, therefore, stimulates VEGF release. In the entire sample, circulating progenitor counts correlated directly with 

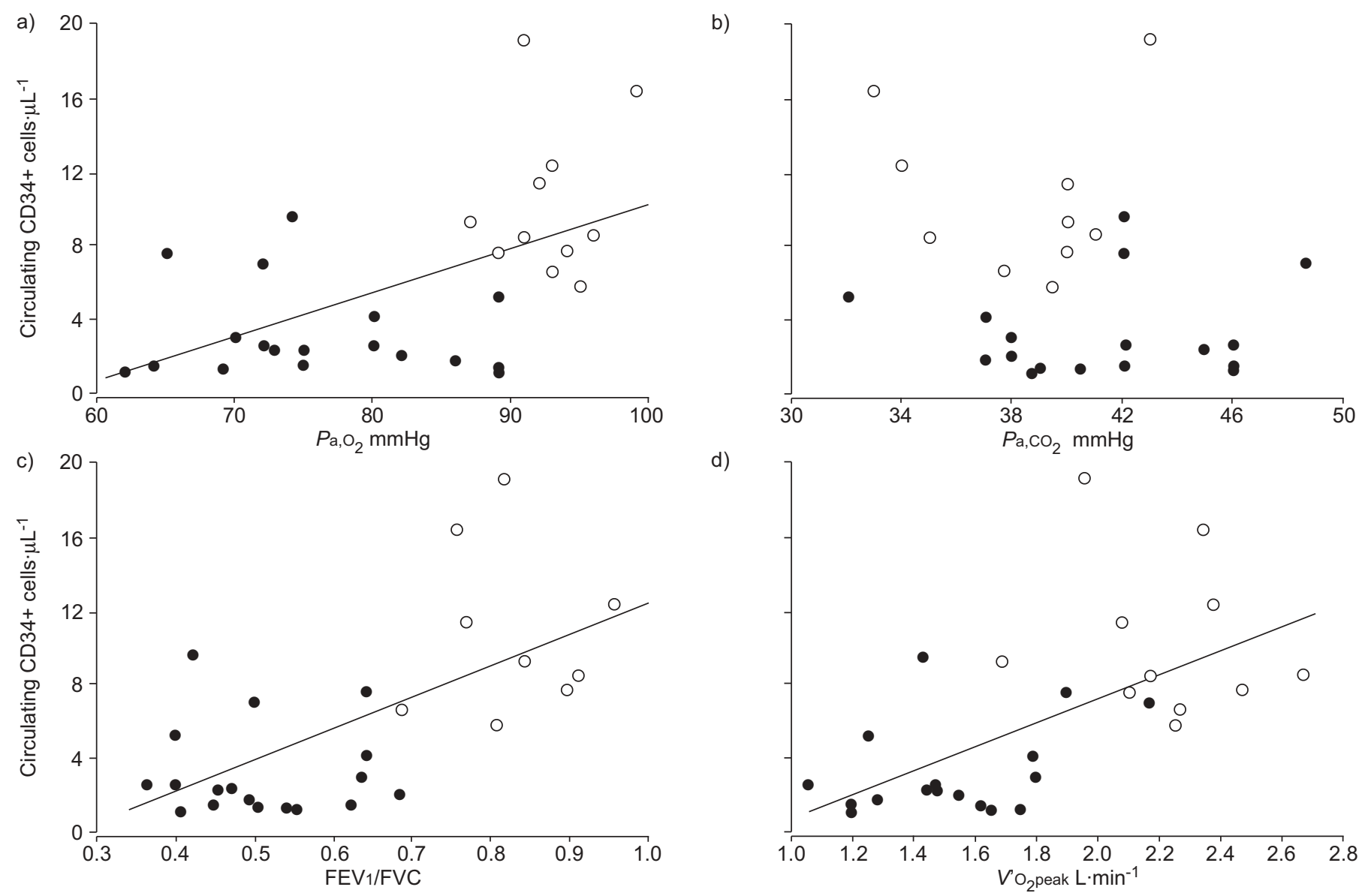

d)

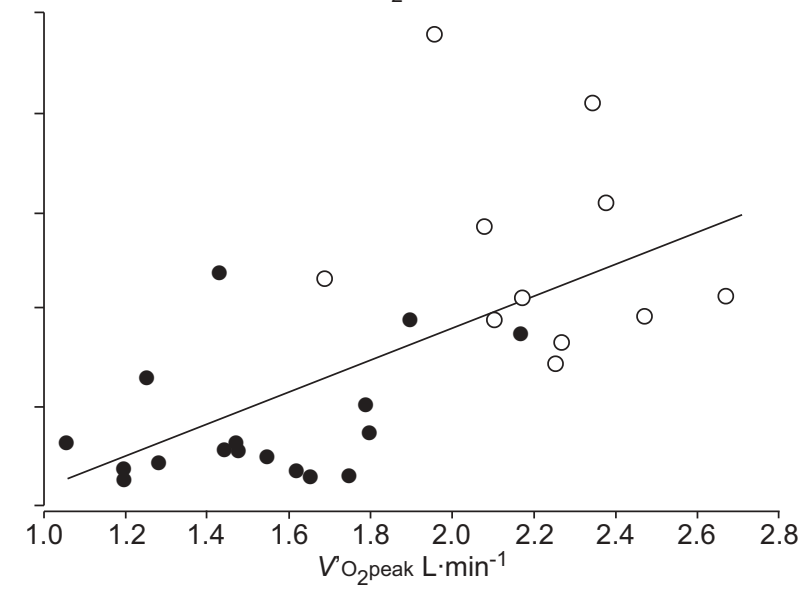

FIGURE 6. Correlations between CD34+ versus: a) arterial oxygen tension $\left(\mathrm{Pa}_{\mathrm{a}} \mathrm{O}_{2} ; \mathrm{r}^{2}=0.30, \mathrm{p}<0.05\right)$; b) carbon dioxide arterial tension $\left(\mathrm{Pa}_{\mathrm{a}} \mathrm{CO}\right)$; $\left.\mathrm{C}\right)$ forced expiratory volume in one second ( $F E V 1)$ /forced vital capacity (FVC); and d) peak oxygen uptake $\left(V^{\prime} \mathrm{O}_{2}\right.$ peak). $\bullet$ : chronic obstructive pulmonary disease (COPD) patients; $\bigcirc$ : control subjects. $1 \mathrm{mmHg}=0.133 \mathrm{kPa}$.

$V^{\prime} \mathrm{O}_{2}$ peak and indices of COPD severity such as FEV1 and $\mathrm{Pa}, \mathrm{O}_{2}$ tension. Overall, the current data indicates that the bone marrow is an important, previously unrecognised, systemic target in the pathophysiology of COPD.

To the best of the authors' knowledge, this study is the first to report that circulating progenitors are decreased in moderateto-severe COPD. However, the current data only allow the indirect estimation of haemopoietic function, and detailed investigations on possible mechanism(s) will require invasive bone marrow sampling. Despite this limitation, the current results do provide some information. Normal peripheral blood cell counts in COPD patients do not support decreased cell production and/or release, as a likely explanation for the current authors findings, at least where the haemopoietic compartment is concerned. WBC counts were higher in COPD patients than control subjects and platelet counts were in the normal range. Only one subject in each group showed slightly reduced haemoglobin concentration, confirming the low prevalence of anaemia in COPD [5], whereas $80 \%$ of the COPD patients showed greatly reduced CD34+ cells compared with the control subjects.

Low circulating progenitor counts may be secondary to defects in cell mobilisation mechanisms. The current authors tested this hypothesis, but found normal expression of adhesion molecules implicated in progenitor homing and migration (very late activation antigen-4 (VLA-4), chemokine (CC motif) receptor 5 (CCR5), C-X-C motif chemokine receptor 4 (CXCR4)) on CD34+ cells, lymphocytes and monocytes of COPD patients (unpublished observations: Testa U., Istituto Superiore di Sanita', Rome, Italy). The data in COPD patients, herefore, mimicked the low proliferation of CD34+ cells recently found in patients with chronic ischemic heart disease [18], which occurred in the absence of obvious mobilisation defects.

The present authors also tested whether insufficient haemopoietic stimulation may occur in COPD patients. Plasma Flt3 ligand and KL concentrations, both being important haemopoietic growth factors [26], were similar in COPD patients and controls. Furthermore, Flt3 ligand concentrations increased after exercise in COPD patients, similar to data obtained in athletes after intense exercise [20,21]. No difference was found in Flt3 ligand expression on CD34+ cells or monocytes between COPD and controls (data not shown), discounting the possibility that the increase in Flt3 ligand could be secondary to a lack of receptors in COPD patients. Altogether, insufficient bone marrow stimulation in COPD is not supported by the current results.

Inflammatory mediators could be involved in the pathogenesis of low circulating precursor counts in COPD. The evidence in 



FIGURE 7. a) AC133+ cells, b) plasma vascular endothelial growth factor (VEGF), c) endothelial cell colony-forming units (EC-CFU, reported as colony number per mL of blood) and d) plasma hepatocyte growth factor (HGF), at baseline (BL) and after endurance exercise (Exe), in chronic obstructive pulmonary disease (COPD) patients ( $\square$ ) and in control subjects $(\square)$. Note the marked reduction in AC133+ and EC-CFU cells in COPD patients versus control subjects, and the increase in plasma HGF in COPD patients at BL and at Exe compared with normal subjects. In addition note the increase in plasma VEGF levels in COPD patients at Exe compared with COPD at BL. *: $p<0.05$, COPD versus controls; ${ }^{*}: p<0.05$, Exe versus BL.

favour of this hypothesis is that COPD patients with CD34+ cells in the normal range tended to show lower TNF- $\alpha$ values. In addition, IL-6 and IL-8 concentrations were, on average, higher in COPD patients than in the control subjects. No clear relationship was found between inflammatory marker concentrations and circulating progenitors. Therefore, more data are necessary to confirm the role of inflammation in modulating CD34+ cells in COPD.

Circulating EPCs were also assessed in the current study, with a special regard to exercise, since it is a known physiological stimulus for their release [22]. Similar to haemopoietic cells, EPCs decreased in COPD patients and showed decreased proliferation when compared with the control subjects. A decreased number of EPCs was also observed in other pathological conditions, including coronary artery diseases [17], chronic ischemic heart disease [18], congestive heart failure [30], rheumatoid arthritis [31] and haemodialysis patients [32], all these conditions are associated with an increased cardiovascular risk. It was suggested in these pathological conditions that the decreased number of circulating EPCs might be related to impaired neovascularisation and could contribute to the increased cardiovascular risk observed in these conditions. Importantly, a recent study by WERNER et al. [33] provided clear evidence that the level of circulating EPCs predicts the occurrence of cardiovascular events and death from cardiovascular causes and helps to identify patients who are at an increased cardiovascular risk. The same could apply for COPD patients. In congestive heart failure [30] and rheumatoid arthritis [31], it was proposed as playing an inhibitory role for TNF- $\alpha$. The biochemical mechanisms responsible for the decreased EPC number in COPD patients remains to be determined.

Exercise did not increase EPCs in either group, possibly because of insufficient intensity and/or duration of the test. However, the pattern of release of pro-angiogenetic factors differed greatly between COPD patients and controls. COPD patients showed two-fold increase in VEGF and HGF levels compared with the control subjects at rest, but only VEGF increased further after exercise. HGF, but not VEGF, concentrations correlated inversely with the results of the clonogenic tests. Both VEGF [27] and HGF [28] are pro-angiogenetic factors, but their action profiles are different. VEGF is a marker of activation of the hypoxic pathway [34], and its increase in COPD patients suggests the occurrence of tissue hypoxia, especially post-exercise.

HGF is a growth factor for hepatocytes, melanocytes, keratinocytes and endothelial cells [35], and is a pulmotrophic factor for the regeneration of an injured lung [36,37]. Through its 

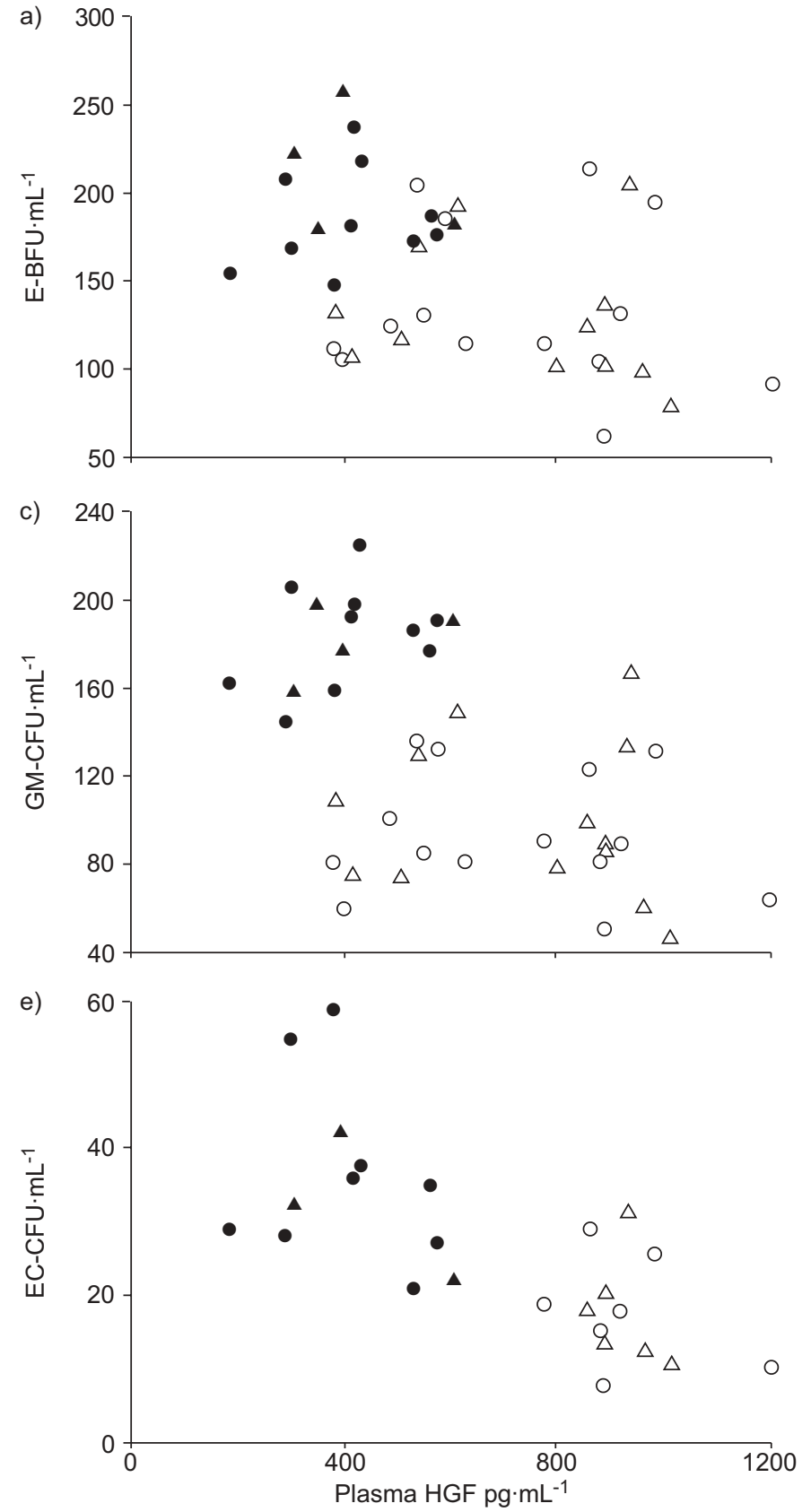

b)

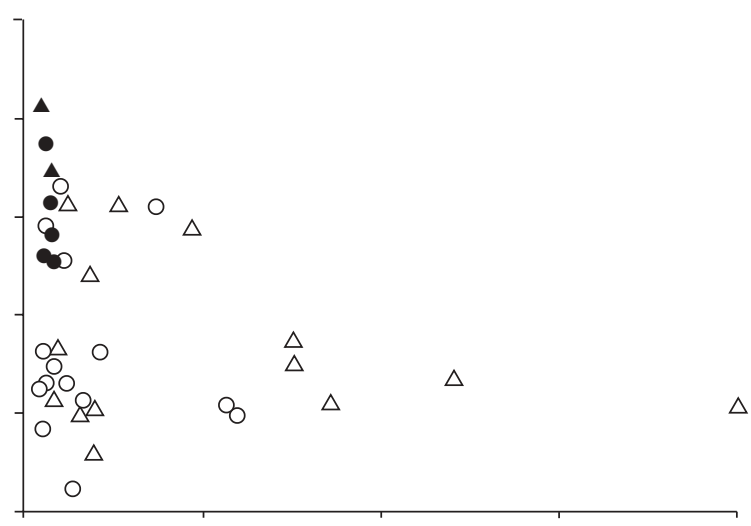

d)

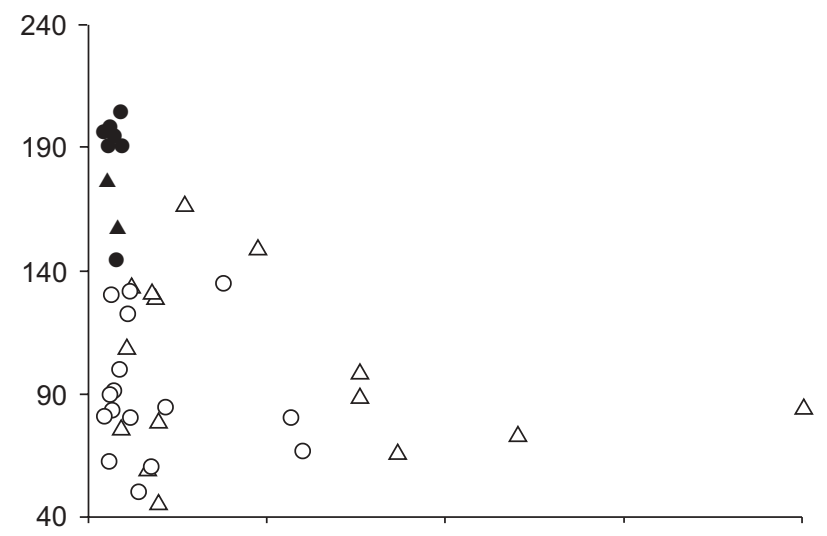

f)

FIGURE 8. Correlation between plasma hepatocyte growth factor (HGF; a, c, e) and vascular endothelial growth factor (VEGF; b, $d$, f) versus a) erythrocyte burst forming units (E-BFU: $\left.r^{2}=0.55, p<0.0001\right)$; b) E-BFU $\left(r^{2}=0.10, p=0.06\right.$, not significant); c) granulocyte-monocyte colony-forming units $\left.\left(G M-C F U: r^{2}=0.64, p<0.0001\right) ; d\right)$ GM-CFU $\left(r^{2}=0.10, p=0.06\right.$, not significant); e) endothelial cell colony-forming units (EC-CFU: $\left.r^{2}=0.46, p<0.0005\right)$; and f) EC-CFU ( $r^{2}=0.09$, not significant). $O$ : chronic obstructive pulmonary disease (COPD) patients at baseline; $\bullet$ : control subjects at baseline; $\triangle$ : COPD patients after exercise; $\mathbf{\Lambda}$ : control subjects after exercise. The $r^{2}$ values are for the entire group of subjects studied (i.e. COPD patients and control subjects combined).

c-met receptor, HGF exerts multiple biological activities, such as stimulation of epithelial alveolar proliferation and mobility [38], and the induction of branching tubule formation. In the lung, alveolar macrophages, endothelial cells [39], bronchial cells [40] and fibroblasts [38] produce HGF. Due to the increased secretion in an injured lung, HGF is presumed to have an important role in the wound healing of pulmonary epithelium [41]. Thus, plasma HGF levels have been found to increase in vascular occlusion [42], COPD [43], lung inflammatory diseases [44] and idiopathic lung fibrosis [43]. In addition to the effect of HGF on alveolar epithelium, HGF stimulates the recruitment of EPCs in the injured lung and stimulates the proliferation of bone marrow derived and resident endothelial cells [45]. The stimulatory effect of HGF on endothelial proliferation is greatly potentiated when it acts in combination with VEGF [46].

In addition to the increase in angiogenetic mediators, progenitor counts showed a relationship with the severity of 


\begin{tabular}{|c|c|c|c|c|}
\hline \multirow[t]{3}{*}{ TABLE 5} & \multicolumn{4}{|c|}{$\begin{array}{l}\text { Biochemical analyses on plasma/serum in } \\
\text { chronic obstructive pulmonary disease (COPD) } \\
\text { patients and control subjects at baseline (BL) } \\
\text { and after endurance exercise (Exe) }\end{array}$} \\
\hline & \multicolumn{2}{|c|}{ COPD patients } & \multicolumn{2}{|c|}{ Control subjects } \\
\hline & BL & Exe & BL & Exe \\
\hline LDH U. $\mathbf{L}^{-1}$ & $302 \pm 73$ & $326 \pm 130$ & $278 \pm 65$ & $325 \pm 46$ \\
\hline CK U. $\mathrm{L}^{-1}$ & $89 \pm 56$ & $114 \pm 66$ & $113 \pm 63$ & $130 \pm 52$ \\
\hline $\mathrm{TNF}-\alpha \mathrm{pg} \cdot \mathrm{mL}^{-1}$ & $2.17 \pm 1.05$ & $1.75 \pm 0.76$ & $1.36 \pm 1.12$ & $1.51 \pm 1.30$ \\
\hline IL-6 pg $\cdot \mathrm{mL}^{-1}$ & $3.7 \pm 1.7$ & $4.0 \pm 1.9$ & $2.5 \pm 1.2$ & $2.4 \pm 1.2$ \\
\hline $\mathrm{IL-8} \mathbf{p g} \cdot \mathrm{mL}^{-1}$ & $225 \pm 526$ & $64 \pm 108$ & $53 \pm 72$ & $44 \pm 42$ \\
\hline Cortisol $\mathbf{n g} \cdot \mathrm{mL}^{-1}$ & $18.0 \pm 6.6$ & $20.9 \pm 6.6$ & $22.4 \pm 8.5$ & $18.7 \pm 2.3$ \\
\hline Flt3 ligand $\mathrm{pg} \cdot \mathrm{mL}^{-}$ & $122.4 \pm 89.4$ & $158.8 \pm 100.7^{*}$ & $118.8 \pm 84.1$ & $124.6 \pm 89.5$ \\
\hline VEGF pg $\cdot \mathrm{mL}^{-1}$ & $69 \pm 68^{\#}$ & $201 \pm 205^{\#, 9}$ & $26 \pm 8$ & $27 \pm 5$ \\
\hline
\end{tabular}

Data are presented as mean \pm SD. LDH: lactate dehydrogenase; CK: creative kinase; TNF- $\alpha$ : tumour necrosis factor- $\alpha$; IL: interleukin; Flt3: FMS-like tyrosine kinase 3; VEGF: vascular endothelial growth factor. ${ }^{*}: p<0.05$ versus baseline (paired t-test); ${ }^{*}: p<0.05$ for comparison between COPD and control groups (Mann-Whitney test); ${ }^{\top}: p<0.03$ versus baseline (Wilcoxon test)

hypoxaemia. The effects of low oxygen tensions on progenitors in vivo are poorly defined, but the human bone marrow is known to be a relatively hypoxic environment under physiological conditions [47]. In addition, hypoxic gradients may be important in regulating progenitor trafficking [48]. Exposure to hypoxia in vitro increased the maturation rate of CD34+ cells, while maintaining early precursors in a quiescent state [23, 24]. The current authors did not observe preferential release of less immature precursors in more hypoxaemic COPD patients; rather, all CD34+ subpopulations tested were uniformly decreased (table 4).

Depression in the number and function of circulating progenitors also correlated with the severity of airway obstruction and the degree of physical fitness, suggesting that depletion of CD34+ cells may be proportional to COPD severity. A large number of patients with COPD at different stages need to be studied to confirm this hypothesis.

Finally, CD34+ cells may be low in COPD patients due to an increase in peripheric utilisation. The current authors hypothesise that a high turnover of precursors may occur in COPD, possibly related to tissue repair. Skeletal muscle may be a potential target tissue for progenitors for the following reasons. 1) CD34+ cells can migrate into muscle connective tissue and satellite cell niches [49]. 2) Exercising mice showed a higher percentage of bone marrow-derived muscle cells compared with sedentary mice [10], indicating precursor engraftment in response to muscle injury. In the current authors' previous study, decreased CD34+ cell counts were found a few hours after a marathon race, suggesting peripheral utilisation of precursors [20]. Alternatively, decreased EPCs in COPD patients may blunt the increase in muscle perfusion evoked by hypoxia [27]. Unfortunately, muscle biopsies were not obtained in the present study and association between lowprogenitor counts and muscle damage remains speculative.
The major limitation of the present study is that the group of subjects studied was small and far from representative of the entire clinical spectrum of COPD. Nevertheless, the difference in CD34+ cells between COPD patients and age-matched controls was large, indicating a likely relevant effect of the disease on circulating precursors.

In conclusion, circulating CD34+ cells and endothelial progenitor counts were decreased in most patients with moderate-to-severe chronic obstructive pulmonary disease and correlated with hypoxaemia, severity of airway obstruction, and peak oxygen consumption. The current data suggests a possible link between systemic inflammation and a decrease in circulating progenitors, as suggested in other pathological conditions. The current authors conclude that bone marrow should be considered as a previously unrecognised systemic target of chronic obstructive pulmonary disease.

\section{REFERENCES}

1 Agusti AG, Noguera A, Sauleda J, Sala E, Pons J, Busquets $X$. Systemic effects of chronic obstructive pulmonary disease. Eur Respir J 2003; 21: 347-360.

2 Noguera A, Busquets X, Sauleda J, Villaverde JM, MacNee W, Agustì AG. Expression of adhesion molecules and $G$ proteins in circulating neutrophils in chronic obstructive pulmonary disease. Am J Respir Crit Care Med 1998; 158: 1664-1668.

3 Di Stefano A, Capelli A, Lusuardi M, et al. Severity of airflow limitation is associated with severity of airway inflammation in smokers. Am J Respir Crit Care Med 1998; 158: 1277-1285.

4 Van Eeden SF, Hogg JC. The response of human bone marrow to chronic cigarette smoking. Eur Respir J 2000; 15 : 915-921.

5 John M, Hoernig S, Doehner W, Okonko DD, Witt C, Anker SD. Anemia and inflammation in COPD. Chest 2005; 127: 825-829.

6 Chambellan A, Chailleux E, Similowski T, and the ANTADIR Observatory Group. Prognostic value of hematocrit in patients with severe chronic obstructive pulmonary disease receiving long term oxygen therapy. Chest 2005; 128: 1201-1208.

7 Terstappen LW, Huang S, Safford M, Lansdorp PM, Loken MR. Sequential generation of haematopoietic colonies derived from single nonlineage committed CD34+CD38- progenitor cells. Blood 1991; 77: 1218-1227.

8 Kotton DN, Ma BY, Cardoso WV, et al. Bone marrowderived cells as progenitors of lung alveolar epithelium. Development 2001; 128: 5181-5188.

9 Suratt BT, Cool CD, Serls AE, et al. Human pulmonary chimerism after haematopoietic stem cell transplantation. Am J Respir Crit Care Med 2003; 168: 318-322.

10 LaBarge MA, Blau HM. Biological progression from adult bone marrow to mononucleate muscle stem cells to multinucleate muscle fiber in response to injury. Cell 2002; 111: 589-601.

11 Agusti AG, Sauleda J, Miralles C, et al. Skeletal muscle apoptosis and weight loss in chronic obstructive pulmonary disease. Am J Respir Crit Care Med 2002; 166: 485-489. 
12 Gosker HR, Kubat B, Schaart G, van der Vusse GJ, Wouters EF, Schols AM. Myopathological features in skeletal muscle of patients with chronic obstructive pulmonary disease. Eur Respir J 2003; 22: 280-285.

13 Agustí A, Morlá M, Sauleda J, Saus C, Busquets X. NF-kB activation and iNOS upregulation in skeletal muscle of patients with COPD and low body weight. Thorax 2004; 59: 483-487.

14 Gehling UM, Ergün S, Schumacher U, et al. In vitro differentiation of endothelial cells from AC133-positive progenitor cells. Blood 2000; 95: 3106-3112.

15 Assmus B, Schächinger V, Teupe C, et al. Transplantation of progenitor cells and regeneration enhancement in acute myocardial infarction (TOPCARE-AMI). Circulation 2002; 106: 3009-3017.

16 Tateishi-Yuyama E, Matsubara H, Murohara $\mathrm{T}$, et al. Therapeutic angiogenesis for patients with limb ischaemia by autologous transplantation of bone-marrow cells: a pilot study and a randomised controlled trial. Lancet 2002; 360: 427-435.

17 Vasa M, Fichtlscherer S, Aicher A, et al. Number and migratory activity of circulating endothelial progenitor cells inversely correlate with risk factors for coronary artery disease. Circ Res 2001; 89: E1-E7.

18 Heeschen C, Lehmann R, Honold J, et al. Profoundly reduced neovascularization capacity of bone marrow mononuclear cells derived from patients with chronic ischemic heart disease. Circulation 2004; 109: 1615-1622.

19 Laufs U, Werner N, Link A, et al. Physical training increases endothelial progenitor cells, inhibits neointima formation, and enhances angiogenesis. Circulation 2004; 109: 220-226.

20 Bonsignore MR, Morici G, Santoro A, et al. Circulating haematopoietic progenitor cells in runners. J Appl Physiol 2002; 93: 1691-1697.

21 Morici G, Zangla D, Santoro A, et al. Supramaximal exercise mobilizes haematopoietic progenitors and reticulocytes in athletes. Am J Physiol Regul Integr Comp Physiol 2005; 289: 496-503.

22 Rehman J, Li J, Parvathaneni L, et al. Exercise acutely increases circulating endothelial progenitor cells and monocyte-/macrophage-derived angiogenic cells. J Am Coll Cardiol 2004; 43: 2314-2318.

23 Danet GH, Pan Y, Luongo JL, Bonnet DA, Simon MC. Expansion of human SCID-repopulating cells under hypoxic conditions. J Clin Invest 2003; 112: 126-135.

24 Hevehan DL, Papoutsakis ET, Miller WM. Physiologically significant effects of $\mathrm{pH}$ and oxygen tension on granulopoiesis. Exp Hematol 2000; 28: 267-275.

25 Palange P, Forte S, Onorati P, Manfredi F, Serra P, Carlone S. Ventilatory and metabolic adaptations to walking and cycling in patients with COPD. I Appl Physiol 2000; 88: 1715-1720.

26 Lyman SD, Jacobsen SE. c-kit ligand and Flt3 ligand: stem/ progenitor cell factors with overlapping yet distinct activities. Blood 1998; 91: 1101-1134.

27 Gavin TP, Robinson CB, Yeager RC, England JA, Nifong LW, Hickner RC. Angiogenic growth factor response to acute systemic exercise in human skeletal muscle. J Appl Physiol 2004; 96: 19-24.
28 Bussolino F, Di Renzo MF, Ziche M, et al. Hepatocyte growth factor is a potent angiogenic factor which stimulates endothelial cell motility and growth. J Cell Biol 1992; 119: 629-641.

29 Ostrowski K, Rohde T, Asp S, Schjerling P, Pedersen BK. Pro- and anti-inflammatory cytokine balance in strenuous exercise in humans. J Physiol 1999; 515: 287-291.

30 Valgimigli M, Rigolin GM, Fucili A, et al. CD34+ and endothelial progenitor cells in patients with various degrees of congestive heart failure. Circulation 2004; 110: 1209-1212.

31 Grisar J, Aletaha D, Steiner CW, et al. Depletion of endothelial progenitor cells in the peripheral blood of patients with rheumatoid arthritis. Circulation 2005; 111: 204-211.

32 Eizawa T, Murakami Y, Mtsui K, et al. Circulating endothelial progenitor cells are reduced in hemodialysis patients. Curr Med Res Opin 2003; 19: 627-633.

33 Werner N, Kosiol S, Schiegl T, et al. Circulating endothelial progenitor cells and cardiovascular outcomes. N Engl J Med 2005; 353: 999-1007.

34 Huang LE, Bunn HF. Hypoxia-inducible factor and its biomedical relevance. J Biol Chem 2003; 278: 19575-19578.

35 Matsumoto K, Nakamura T. Hepatocyte growth factor: molecular structure and implications for a central role in liver regeneration. J Gastroenterol Hepatol 1991; 6: 509-519.

36 Sakamaki Y, Matsumoto K, Mizuno S, Nakamura T. Hepatocyte growth factor stimulates proliferation of respiratory epithelial cells during postpneumonectomy compensatory lung growth in mice. Am J Respir Cell Mol Biol 2002; 26: 525-533.

37 Yanagita K, Matsumoto K, Sekiguchi K, Ishibashi H, Niho Y, Nakamura T. Hepatocyte growth factor may act as a pulmotrophic factor on regeneration after acute lung injury. J Biol Chem 1993; 268: 21212-21217.

38 Stoker M, Gherardi E, Perryman M, Gray J. Scatter factor is a fibroblast-derived modulator of epithelial cell mobility. Nature 1987; 327: 239-242.

39 Wolf HK, Zarnegar R, Michalopoulos GK. Localization of hepatocyte growth factor in human and rat tissues: an immunochemical study. Hepatology 1991; 14: 488-494.

40 Yanagita K, Nagaike M, Ishibashi H, Niho Y, Matsumoto K, Nakamura T. Lung may have endocrine function producing hepatocyte growth factor in response to injury of distal organs. Biochem Biophys Res Commun 1992; 182: 802-809.

41 Sato N, Takahashi H. Hepatocyte growth factor promotes growth and lumen formation of fetal lung epithelial cells in primary culture. Respirology 1997; 3: 185-191.

42 Yoshitomi Y, Kojima S, Umemoto T, et al. Serum hepatocyte growth factor in patients with peripheral arterial occlusive disease. J Clin Endocrinol Metab 1999; 84: 2425-2428.

43 Aharinejad S, Taghavi S, Klepetko W, Abraham D. Prediction of lung-transplant rejection by hepatocytes growth factor. Lancet 2004; 363: 1503-1508.

44 Huang MS, Tsai MS, Wang TH, et al. Serum hepatocyte growth factor levels in patients with inflammatory lung diseases. Kaohsiung J Med Sci 1999; 15: 195-201.

45 Ishizawa K, Kubo H, Yamada M, et al. Hepatocyte growth factor induces angiogenesis in injured lungs through 
mobilizing endothelial progenitor cells. Biochem Biophys Res Commun 2004; 324: 276-280.

46 Gerritsen ME. HGF and VEGF: a dynamic duo. Cir Res 2005; 96: 272-273.

47 Harrison JS, Rameshwar P, Chang V, Bandari P. Oxygen saturation in the bone marrow of healthy volunteers. Blood 2002; 99: 394.
48 Ceradini DJ, Kulkarni AR, Callaghan MJ, et al. Progenitor cell trafficking is regulated by hypoxic gradients through HIF-1 induction of SDF-1. Nat Med 2004; 10: 858-864.

49 Dreyfus PA, Chretien F, Chazaud B, et al. Adult bonemarrow-derived stem cells in muscle connective tissue and satellite niches. Am J Pathol 2004; 164: 773-779. 